\title{
Radiosensitization of human glioma cells by tamoxifen is associated with the inhibition of PKC-ı activity in vitro
}

\author{
LEI YANG, XIAOPENG YUAN, JIE WANG, CHENG GU, HAOWEN ZHANG, JIAHUA YU and FENJU LIU
}

\author{
Department of Radiobiology, School of Radiation Medicine and Protection, \\ Medical College of Soochow University, School for Radiological and Interdisciplinary Sciences, Soochow University, \\ Collaborative Innovation Center of Radiation Medicine of Jiangsu Higher Education Institutions, Suzhou 215123, P.R. China
}

Received July 6, 2014; Accepted April 21, 2015

DOI: $10.3892 / \mathrm{ol} .2015 .3195$

\begin{abstract}
The present study aimed to investigate the radiosensitizing effects of tamoxifen (TAM), a non-steroidal anti-estrogen drug, in human glioma A172 and U251 cells in vitro. A colony-forming assay revealed that TAM enhances radiosensitivity in A172 and U251 cells. Treatment with TAM also increased the percentage of apoptotic cells subsequent to ionizing radiation, and increased the expression of apoptotic markers, including cleaved caspase- 3 and poly(ADP-ribose) polymerase. Ionizing radiation induced $\mathrm{G} 2 / \mathrm{M}$ phase arrest, which was alleviated within $24 \mathrm{~h}$ when the radiation-induced DNA damage was repaired. However, flow cytometry analysis revealed that TAM treatment delayed the recovery of cell cycle progression. Additional examination demonstrated that TAM-mediated protein kinase C-ı (PKC-ı) inhibition may lead to the activation of pro-apoptotic B-cell lymphoma 2-associated death promoter, and the dephosphorylation of cyclin-dependent kinase 7 , resulting in increased cell apoptosis and sustained G2/M phase arrest following exposure to radiation. The present data indicate that the radiosensitizing effects of TAM on glioma cells are partly due to the inhibition of PKC-ı activity in vitro.
\end{abstract}

\section{Introduction}

Glioma is the most lethal primary brain tumor, with a median survival time of only 12 months. This tumor is incurable due to the aggressive proliferation and rapid infiltration of glioma cells. Despite advances in surgery and novel modalities in

Correspondence to: Professor Fenju Liu, Department of Radiobiology, School of Radiation Medicine and Protection, Medical College of Soochow University, School for Radiological and Interdisciplinary Sciences, Soochow University, Collaborative Innovation Center of Radiation Medicine of Jiangsu Higher Education Institutions, 199 Ren'ai, Suzhou 215123, P.R. China

E-mail: radiobiology@126.com

Key words: Bad, cyclin-dependent kinase 7, glioma, protein kinase $\mathrm{C}-\mathrm{\iota}$, radiosensitivity, tamoxifen radiotherapy and chemotherapy, the prognosis for patients suffering from this disease remains poor, and even the etiology of glioma remains unclear $(1,2)$. Ionizing radiation is the primary form of therapy subsequent to an optimal surgical resection or biopsy, prolonging median survival for a maximum of 6-8 months (3). However, curative treatment remains poor in spite of the fact that novel methods have increased the therapeutic potential of radiation in tumor therapy. The application of sub-lethal doses of radiation may result in local failure, and may promote the migration and invasion of glioma cells (4).

Tamoxifen (TAM) is a well-known non-steroidal anti-estrogen agent with low toxicity that is widely used to treat estrogen-dependent breast cancer. There have been an increasing number of studies reporting that this agent may also inhibit the growth of estrogen receptor-negative tumors, such as melanoma, malignant peripheral nerve sheath tumors, bladder cancer and glioma (5-8). This indicates that TAM may exert anti-tumor effects in an estrogen receptor-independent manner. Furthermore, the ability of TAM to penetrate the blood-brain barrier facilitates its utilization in treatment of malignant diseases in the central nervous system (9). Although certain intracellular signal transduction pathways, such as protein kinase $\mathrm{C}$ (PKC), transforming growth factor- $\beta$, calmodulin, transcription factor c-Myc, mitogen-activated protein kinase p38 and c-Jun NH2-terminal kinase, have been implicated in TAM-induced apoptosis, the exact molecular mechanism remains elusive (10-13). It has been reported that TAM interferes with the activity of the catalytic subunit of the PKC (14-16), and the activity of PKC is associated with the growth rate of malignant gliomas in vitro $(17,18)$. Therefore, TAM may exert a synergistic effect with radiotherapy and the mechanism may be associated with the activity of PKC.

Studies have revealed that the activity of PKC is significantly upregulated in glioma, and this increase is concordant with the malignant growth rates (19-21). The PKC family contains 12 subtypes classified in three classes based on their requirement for specific activators and cofactors (22-24). PKC-ı, a member of the atypical PKC family, was of particular interest as this kinase is involved in cell growth, proliferation, survival and apoptosis. PKC-ı has been demonstrated to promote survival and prevent apoptosis in non-small-cell lung cancer and gastric carcinoma $(25,26)$, and is highly activated and overexpressed in glioma. The kinase also plays 
a key role in cell cycle progression and proliferation $(27,28)$. These findings indicated that PKC-ı is overexpressed in the hyper-proliferative state of gliomas, and is also associated with the resistance of gliomas to apoptosis in response to treatment with cytotoxic agents or ionizing radiation. Therefore, pharmacological manipulation of PKC-ı activity may restrain tumor cell proliferation and restore susceptibility to apoptosis, presenting a promising method for the treatment of glioma.

In the present study, the radiosensitizing effects of TAM in human glioma A172 and U251 cells were examined in vitro and the mechanisms of TAM-enhanced radiosensitization were also investigated. The present results demonstrated that the inhibition of PKC-ı activity by TAM may, at least in part, radiosensitize glioma cells.

\section{Materials and methods}

Cell culture and irradiation. Human glioma A172 and U251 cells (Cell Bank of Chinese Academy of Sciences, Shanghai, China) were cultured as a monolayer in Dulbecco's modified Eagle's medium supplemented with $10 \%$ fetal bovine serum, $100 \mu \mathrm{g} / \mathrm{ml}$ streptomycin and 100 units $/ \mathrm{ml}$ penicillin at $37^{\circ} \mathrm{C}$ under a humidified atmosphere containing $5 \% \mathrm{CO}_{2}$. TAM was purchased from Sigma-Aldrich (St. Louis, MO, USA) and was dissolved in dimethyl sulfoxide at a concentration of $10 \mathrm{mM}$. The cells were irradiated by $160 \mathrm{kV} \mathrm{X}$-rays at a dose rate of $1.15 \mathrm{~Gy} / \mathrm{min}$ using a RS-2000 Pro Biological Irradiator (Rad Source Technologies, Inc., Alpharetta, GA, USA).

Colony-forming assay. The A172 and U251 cells were plated in triplicate into six-well plates and irradiated with various doses of X-rays $24 \mathrm{~h}$ subsequent to plating. The cells were treated with TAM immediately following irradiation. After $48 \mathrm{~h}$, the TAM-containing medium was replaced with fresh growth medium. Subsequent to being cultured for 12 days, the cells were fixed and stained with $1 \%$ crystal violet and colonies containing $>50$ cells were counted. The survival fraction was calculated as the fraction of colonies divided by that of the control group. The cell survival curves were then fitted using single hit multi-target radiobiological models.

Flow cytometry analysis. A172 or U251 cells were irradiated with 4 Gy X-ray and treated with TAM immediately following irradiation. After 24 or $48 \mathrm{~h}$, the cells were harvested and fixed with $70 \%$ ice-cold ethanol. Subsequent to incubation with RNase A, the cells were stained with $25 \mu \mathrm{g} / \mathrm{ml}$ propidium iodide (PI) for $30 \mathrm{~min}$ on ice. The distribution of the cell cycle was analyzed using a FACSCalibur flow cytometer (BD Biosciences, San Jose, CA, USA). For apoptosis analysis, cells were washed with ice-cold phosphate-buffered saline (PBS) and stained using an Annexin V-phycoerythrin/7-aminoactinomycin D apoptosis detection kit (BD Biosciences). The percentage of apoptotic cells was measured by flow cytometry. At least 10,000 cells were measured for each sample.

Western blotting. The cells were rinsed with ice-cold PBS and lysed by RIPA lysis buffer with protease and phosphatase inhibitors for $20 \mathrm{~min}$ on ice. The cells were then centrifuged at $12,000 \mathrm{x} g$ for $10 \mathrm{~min}$ at $4^{\circ} \mathrm{C}$. Cell lysates containing equal amount of protein were resolved on $10 \%$ SDS-PAGE, and electrically transferred to polyvinylidene difluoride membranes (Bio-Rad Laboratories, Hercules, CA, USA). Non-specific binding was blocked with Tris-buffered saline containing 5\% $(\mathrm{w} / \mathrm{v})$ skim milk for $2 \mathrm{~h}$ at room temperature. The membranes were subsequently incubated with the following antibodies: Rabbit anti-caspase-3 (1:1,000), rabbit anti-poly(ADP-ribose) polymerase (PARP; 1:1,000; Proteintech Group, Chicago, IL, USA), rabbit anti-B-cell lymphoma 2-associated death promoter (Bad; 1:1,000; Epitomics, Burlingame, CA, USA), rabbit antiphosphorylated PKC-ı (p-PKC-ı; 1:1,000), mouse anti-PKC-ı $(1: 1,000)$, rabbit anti-cyclin-dependent kinase 7 (cdk7; 1:2,000), rabbit anti-phosphorylated cdk7 (p-cdk7; 1:500) (Abcam, Cambridge, MA, USA) and mouse anti- $\beta$-actin (1:2,000; Santa Cruz Biotechnology, Inc., Dallas, TX, CA). The membranes were then incubated with a horseradish peroxidase-conjugated secondary antibody. Immunoblotting signals were detected using by using an enhanced chemiluminescence kit (Thermo Fisher Scientific, Inc., Foster City, CA, USA).

Statistical analysis. The data were expressed as the mean \pm standard deviation. Statistical analysis was performed using one-way analysis of variance subsequent to multiple comparisons using the S-N-K method using SPSS 18.0 software (SPSS, Inc., Chicago, IL, USA). P $<0.05$ was considered to indicate a statistically significant difference.

\section{Results}

Treatment with TAM enhances the radiosensitivity of A172 and U251 cells. TAM has been reported to increase the radiosensitivity of several glioma cell lines $(18,29)$. In the present study, the radiosensitizing effects of TAM on the human malignant glioma A172 and U251 cells were explored. The cells were irradiated with various doses of X-rays, and treated with $10 \mu \mathrm{M}$ TAM for 2 days subsequent to irradiation. A colony-forming assay was performed to examine the effects of TAM on the radiosensitivity of A172 and U251 cells. As shown in Fig. 1, treatment with TAM radiosensitized A172 and U251 cells. The sensitivity enhancement ratios were 1.24 and 1.46 in A172 and U251 cells, respectively.

TAM increased radiation-induced apoptosis. In order to investigate the roles of apoptosis in the radiosensitizing effects of TAM, the A172 or U251 cells were stained with phycoerythrin-conjugated Annexin V and flow cytometry analysis was performed. As shown in Fig. 2A, combined treatment consisting of radiation and TAM induced a substantial increase in the apoptotic rate compared to the group treated with radiation alone. Subsequently, western blotting was performed to assess the activation of the apoptosis signaling pathway. It was found that TAM upregulated the expression levels of cleaved caspase-3 and cleaved PARP in A172 and U251 cells (Fig. 2B).

TAM enhanced radiation-induced $G 2 / M$ arrest. In order to investigate the effect of TAM or TAM combined with radiation on cell cycle progression, flow cytometry analysis was performed to reveal the cell cycle distribution at various time points. $\mathrm{G} 2 / \mathrm{M}$ phase arrest was induced by radiation and 

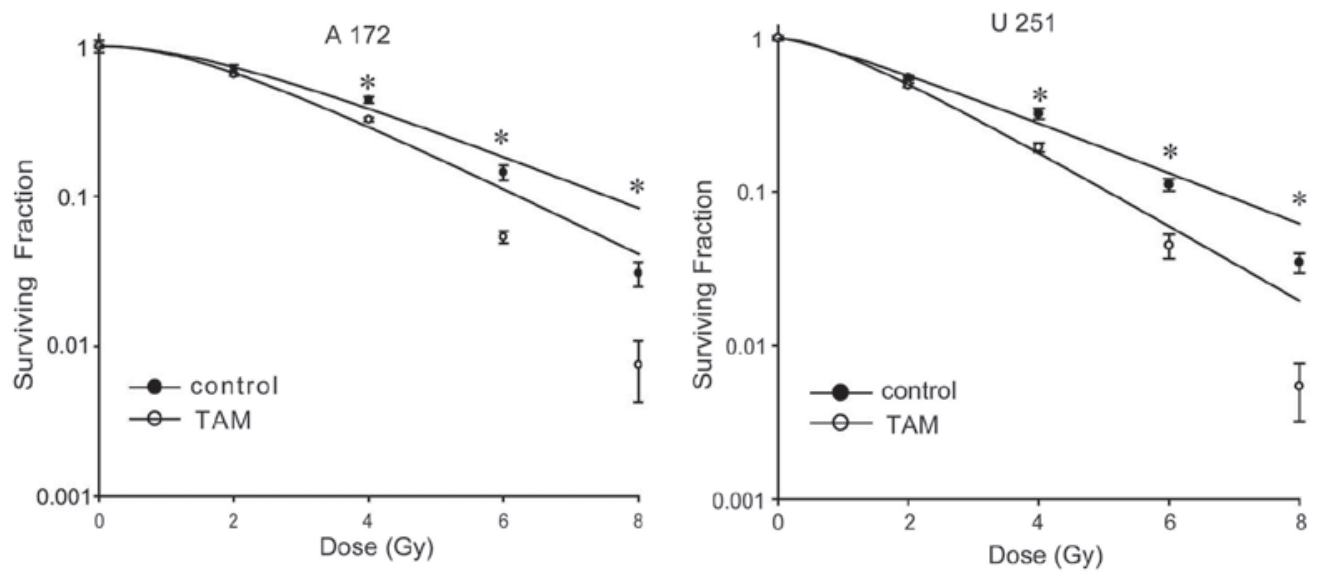

Figure 1. TAM enhances the radiosensitivity of the glioma A172 and U251 cell lines. The A172 and U251 cells were treated with various doses of X-ray irradiation and $10 \mu \mathrm{M}$ TAM for $48 \mathrm{~h}$. A clonogenic survival assay was then performed. "P<0.05 vs control (n=3). TAM, tamoxifen.

A

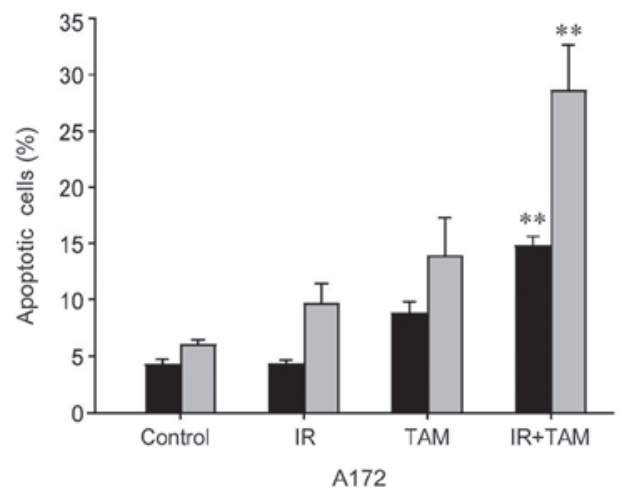

B

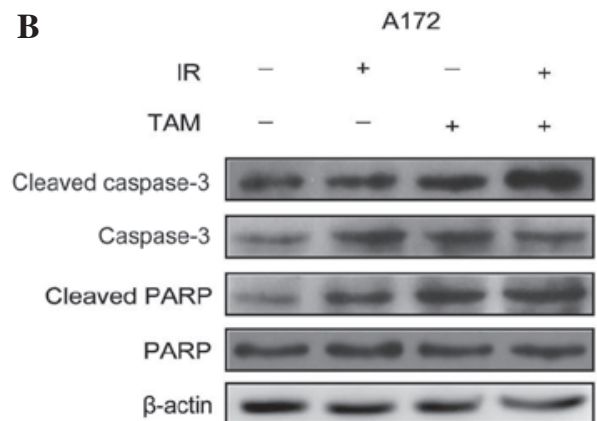

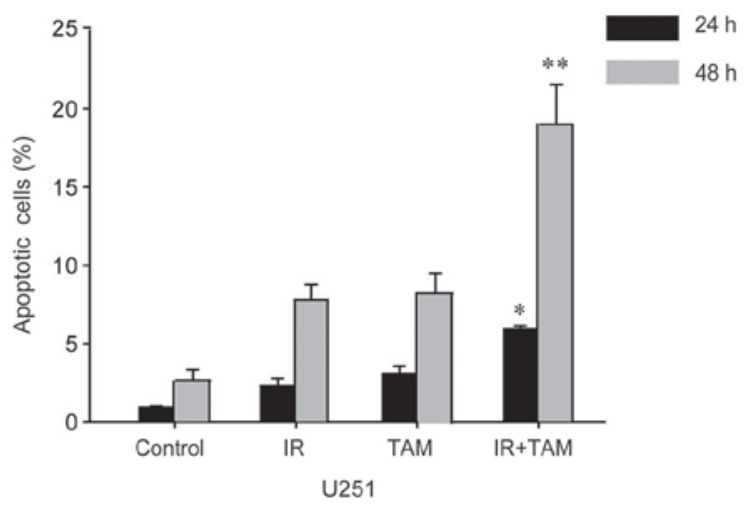

U251

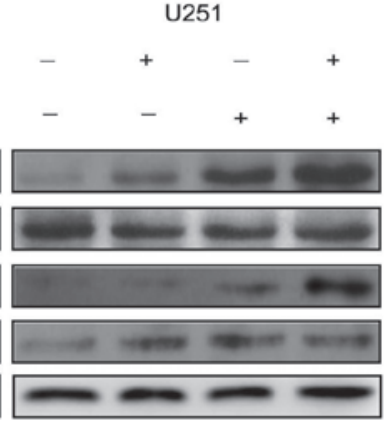

Figure 2. TAM enhances radiation-induced apoptosis in A172 and U251 cells. (A) Flow cytometry was used to determine A172 and U251 cell apoptosis following treatment with either 4-Gy X-rays or $10 \mu \mathrm{M}$ TAM alone or in combination for $24 \mathrm{~h}$ or $48 \mathrm{~h}$. ${ }^{*} \mathrm{P}<0.05$ and ${ }^{* *} \mathrm{P}<0.01$ vs. IR group. (B) Western blot analysis was performed to evaluate the expression of activated apoptotic markers. $\beta$-actin was used as the loading control. TAM, tamoxifen; IR, irradiation; PARP, poly(ADP-ribose) polymerase.

the percentage of $\mathrm{G} 2 / \mathrm{M}$ phase cells was gradually reduced at $24 \mathrm{~h}$ (Fig. 3), indicating the completion of DNA damage repair and reentering of cell cycle progression. Treatment with TAM did not increase radiation-induced $\mathrm{G} 2 / \mathrm{M}$ phase arrest, but did maintain G2/M phase arrest, therefore postponing cell cycle progress. Notably, treatment with TAM alone induced G0/G1 phase arrest, suggesting the inhibition of DNA synthesis.

TAM suppressed the activation of PKC-८ signaling. The estrogen-independent antitumor activity of TAM may be partly due to the inhibitory effects of TAM on PKC (11). It has been reported that the expression and function of atypical PKC-ı is highly upregulated in glioma cells (28). In the present study, western blot analysis revealed that the expression levels of p-PKC-ı (T555) were decreased by TAM treatment in A172 and U251 cells (Fig. 4). In glioma T98 G and U87MG cells, PKC-ı may act as a Bad kinase, thereby phosphorylating and negatively regulating the pro-apoptotic function of Bad. Similarly, combined administration of TAM and radiation induced a significant increase in the levels of Bad protein in A172 and U251 cells (Fig. 4). In addition, PKC-ı may phosphorylate Cdk7 in a cell cycle-dependent manner (27). As shown in Fig. 4, 

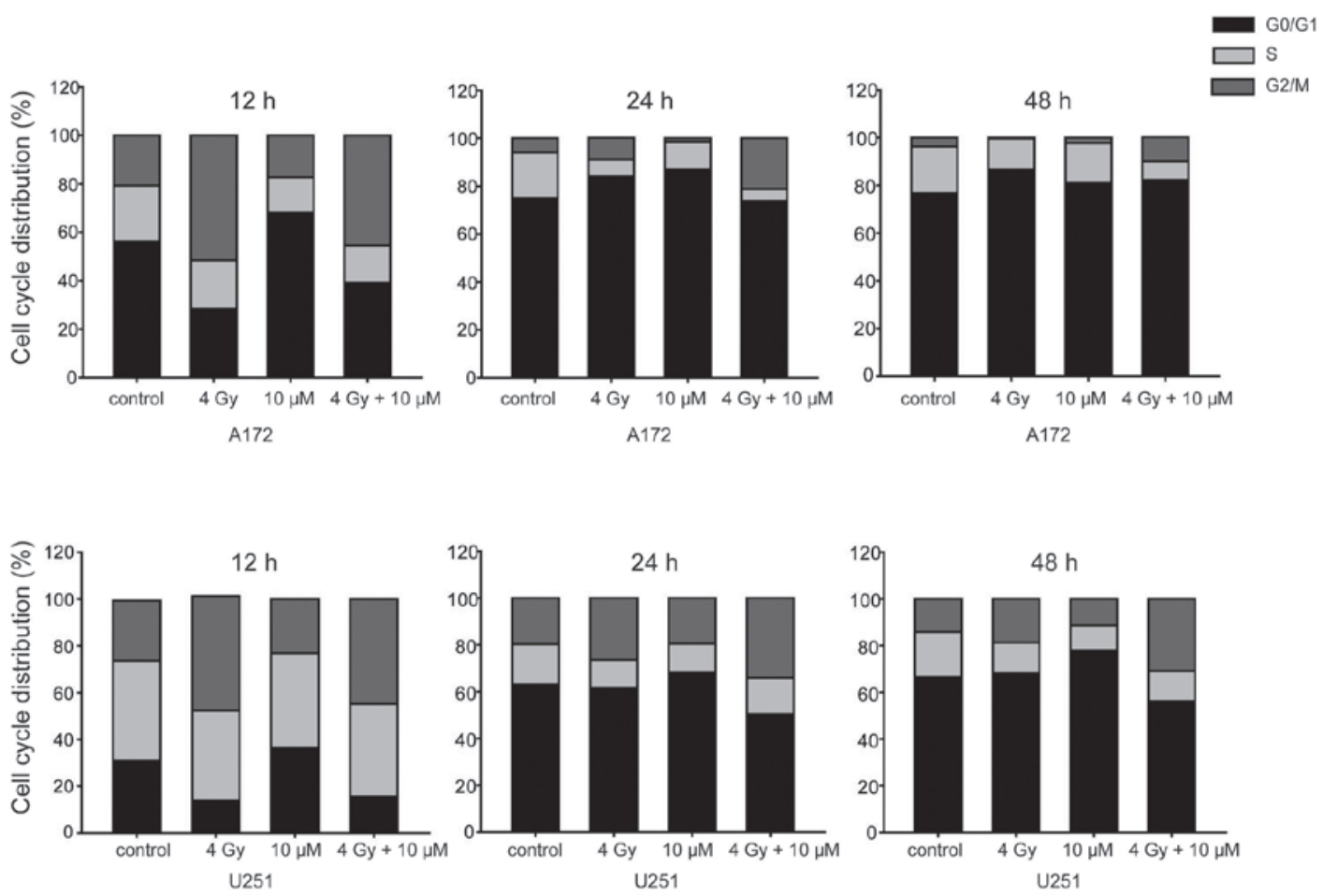

Figure 3. TAM alters radiation-induced cell cycle arrest. A172 and U251 cells were treated with either 4-Gy X-rays or $10 \mu \mathrm{M}$ TAM alone or in combination for $12 \mathrm{~h}, 24 \mathrm{~h}$ and $48 \mathrm{~h}$. Flow cytometry was employed to investigate the cell cycle distribution of glioma cells. TAM, tamoxifen.

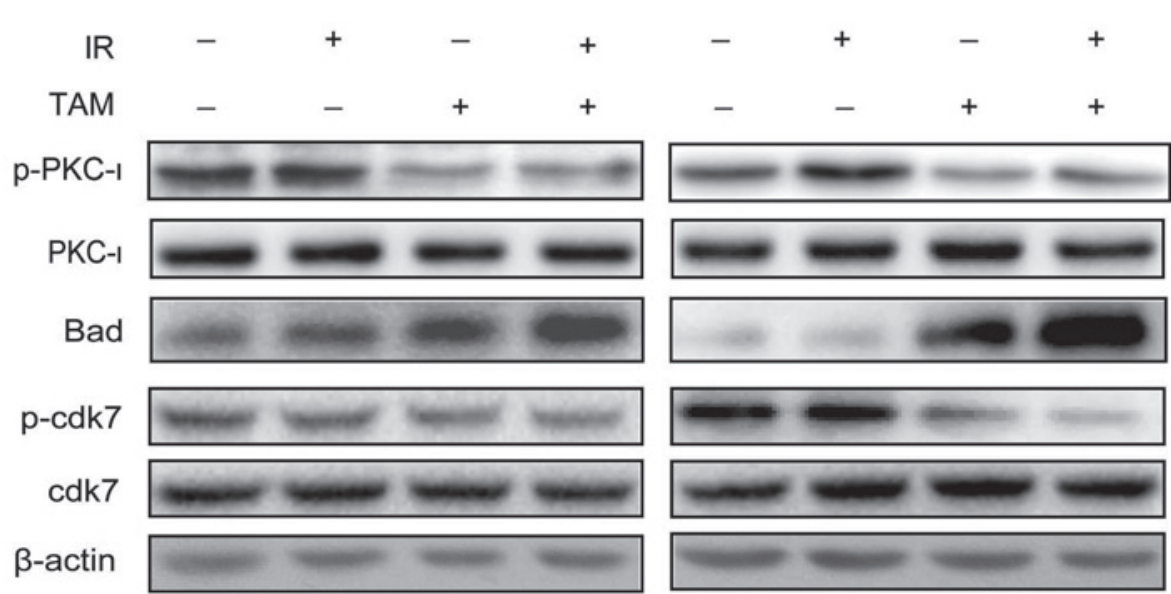

Figure 4. Inhibition of PKC-ı signaling by treatment with TAM. A172 or U251 cells were treated with either 4 Gy X-ray or $10 \mu \mathrm{M}$ TAM alone or in combination for $24 \mathrm{~h}$. Western blot analysis was performed to detect the expression of p-PKC-ı, Bad and p-cdk7. $\beta$-actin was used as the loading control. TAM, tamoxifen; IR, irradiation; PKC-ı, protein kinase C-ı; p-PKC-ı, phosphorylated PKC-ı; Bad, B-cell lymphoma 2-associated death promoter; cdk7, cyclin-dependent kinase 7; p-cdk7, phosphorylated cdk7.

the expression of p-cdk7 was significantly decreased in glioma cell lines subsequent to treatment with TAM. These results suggested that the increased radiation-induced cell apoptosis, as well as the prolonged cell cycle arrest, may be in part due to the downregulation of PKC-ı signaling by TAM treatment.

\section{Discussion}

In the present study, the colony-forming assay revealed the radiosensitizing effects of TAM on the human malignant glioma A172 and U251 cells. The number of apoptotic cells was considerably increased by treatment with TAM and radiation. In addition, TAM treatment did not induce an increase in the number of cells that underwent $\mathrm{G} 2 / \mathrm{M}$ arrest subsequent to radiation exposure, but delayed the recovery of cell cycle progression. The activity of PKC-ı signaling, which plays an important role in the proliferation, apoptosis and cell cycle regulation of glioma cells $(27,28,30)$, was markedly suppressed by TAM.

Ionizing radiation created DNA double strand breaks and activated an integrated DNA damage response, including DNA 
lesion sensing, signal transduction and activation of functional proteins (31). The cellular outcome of the DNA damage response is dependent upon the success of DNA repair. Cells may maintain genome integration if the DNA damage is well repaired; however, by contrast, the cell cycle may arrest at the G2/M checkpoint to allow DNA damage repair, and cells may enter the process of programmed cell death if the DNA damage repair fails (32). Radiation treatment alone induces apoptosis in glioma cells, and TAM enhances the pro-apoptotic effects of radiation, suggesting that TAM interferes with the DNA damage response. Similarly, TAM treatment maintains G2/M phase arrest and prevents cells entering mitosis subsequent to the administration of ionizing radiation. Since the peroxidase-mediated metabolism of TAM was revealed to produce DNA adducts and contribute to the formation of DNA damage (33), treatment with TAM alone induced G0/G1 phase arrest in human glioma cells. Additionally, A172 cells and U251 cells express wild-type p53 and mutant p53 respectively, whereas TAM treatment resulted in an equivalent increase of radiosensitivity in the two cell lines, indicating the radiosensitizing effects of TAM may be independent of p53 status.

At present, the mechanism by which TAM increases the radiosensitivity of glioma cells is not completely clear. A synergistic effect of TAM with radiation in C6 glioma cells has been demonstrated, and may partially be due to the inhibition of PKC activation (18). The atypical PKC family member, PKC-ı was of particular interest as it is a key regulator of cell survival, proliferation, invasion and chemoresistance in glioma $(27,30,34,35)$. The present results revealed an inhibitory role of TAM in the expression levels of p-PKC-ı, which may participate in the radioresistance of glioma cells. In the human glioma T98G and U87MG cell lines, PKC-ı is able to directly phosphorylate $\mathrm{Bad}$, and restrain its pro-apoptotic function (30). PKC-ı may play an equivalent role in A172 and U251 cells, since inhibition of PKC-ı by TAM was revealed to increase the expression of Bad. In metazoans, the only known CDK-activating kinase is Cdk7 (36), which was revealed to be phosphorylated by PKC-ı in a cell cycle dependent manner $(27,37)$. Inhibiting $\mathrm{Cdk} 7$ in the $\mathrm{G} 2$ phase blocks entry into mitosis and disrupts $\mathrm{Cdk1/cyclin} \mathrm{B} \mathrm{complex} \mathrm{assembly} \mathrm{(38).} \mathrm{It} \mathrm{has} \mathrm{been} \mathrm{reported} \mathrm{that}$ decreased Cdk7 activity led to inactivation of Cdk1 and caused an irreversible $\mathrm{G} 2 / \mathrm{M}$ phase arrest in human gastric carcinoma cells (39). In A172 and U251 cells, the sustained G2/M phase arrest induced by radiation and TAM treatment may be the result of PKC-ı-mediated inactivation of $\mathrm{Cdk} 7$.

In summary, the present data revealed that TAM enhanced the radiosensitivity of human glioma cells, accompanied by increased cell apoptosis and sustained G2/M phase arrest. Mechanistically, the capability of TAM to repress the activation of PKC-ı, as well as its downstream targets Bad and Cdk7, may play an vital role in the radiosensitizing effects on A172 and U251 cells.

\section{Acknowledgements}

This study was supported by the National Natural Science Foundation of China (grant nos., 31270897, 81271682 and 30870585) and the Graduate Innovation Foundation of Medical College of Soochow University and the Priority Academic Program Development of Jiangsu Higher Education Institutions.

\section{References}

1. Parlato C, Barbarisi M, Moraci M and Moraci A: Surgery, radiotherapy and temozolomide in treating high-grade gliomas. Front Biosci 11: 1280-1283, 2006.

2. Stupp R, Mason WP, van den Bent MJ, et al: Radiotherapy plus concomitant and adjuvant temozolomide for glioblastoma. $\mathrm{N}$ Engl J Med 352: 987-996, 2005.

3. Laperriere N, Zuraw L and Cairncross G; Cancer Care Ontario Practice Guidelines Initiative Neuro-Oncology Disease Site Group: Radiotherapy for newly diagnosed malignant glioma in adults: a systematic review. Radiother Oncol 64: 259-273, 2002.

4. Wild-Bode C, Weller M, Rimner A, Dichgans J and Wick W: Sublethal irradiation promotes migration and invasiveness of glioma cells: implications for radiotherapy of human glioblastoma. Cancer Res 61: 2744-2750, 2001.

5. Pu YS, Hsieh TS, Tsai TC, et al: Tamoxifen enhances the chemosensitivity of bladder carcinoma cells. J Urol 154: 601-605, 1995.

6. Liu Z, Kokunai $\mathrm{T}$ and Tamaki N: Tamoxifen interacts with NEU/C-ERBB-2 receptor and inhibits growth of human malignant glioma cell lines. Kobe J Med Sci 47: 131-140, 2001.

7. Kohli L, Kaza N, Coric T, et al: 4-Hydroxytamoxifen induces autophagic death through K-Ras degradation. Cancer Res 73: 4395-4405, 2013.

8. Ribeiro MP, Silva FS, Paixão J, Santos AE and Custódio JB: The combination of the antiestrogen endoxifen with all-trans-retinoic acid has anti-proliferative and anti-migration effects on melanoma cells without inducing significant toxicity in non-neoplasic cells. Eur J Pharmacol 715: 354-362, 2013.

9. Wilking N, Appelgren LE, Carlstrom K, Pousette A and Theve NO: The distribution and metabolism of 14C-labelled tamoxifen in spayed female mice. Acta Pharmacol Toxicol (Copenh) 50: 161-168, 1982.

10. Gundimeda U, Chen ZH and Gopalakrishna R: Tamoxifen modulates protein kinase $\mathrm{C}$ via oxidative stress in estrogen receptor-negative breast cancer cells. J Biol Chem 271: 13504-13514, 1996.

11. Horgan K, Cooke E, Hallett MB and Mansel RE: Inhibition of protein kinase $\mathrm{C}$ mediated signal transduction by tamoxifen. Importance for antitumour activity. Biochem Pharmacol 35: 4463-4465, 1986.

12. Kang Y, Cortina R and Perry RR: Role of c-myc in tamoxifen-induced apoptosis estrogen-independent breast cancer cells. J Natl Cancer Inst 88: 279-284, 1996.

13. Mandlekar S and Kong AN: Mechanisms of tamoxifen-induced apoptosis. Apoptosis 6: 469-477, 2001.

14. Nakadate T, Jeng AY and Blumberg PM: Comparison of protein kinase $\mathrm{C}$ functional assays to clarify mechanisms of inhibitor action. Biochem Pharmacol 37: 1541-1545, 1988.

15. Ramachandran C, Khatib Z, Petkarou A, et al: Tamoxifen modulation of etoposide cytotoxicity involves inhibition of protein kinase $\mathrm{C}$ activity and insulin-like growth factor II expression in brain tumor cells. J Neurooncol 67: 19-28, 2004.

16. O'Brian CA, Liskamp RM, Solomon DH and Weinstein IB: Inhibition of protein kinase $\mathrm{C}$ by tamoxifen. Cancer Res 45: 2462-2465, 1985.

17. Xiao H, Goldthwait DA and Mapstone T: The identification of four protein kinase $\mathrm{C}$ isoforms in human glioblastoma cell lines: $\mathrm{PKC} \alpha$, $\gamma, \varepsilon$ and $\zeta$. J Neurosurg 81: 734-740, 1994.

18. Zhang W, Yamada H, Sakai N, Niikawa S and Nozawa Y: Enhancement of radiosensitivity by tamoxifen in C6 glioma cells. Neurosurgery 31: 725-729, discussion 729-730, 1992.

19. Couldwell WT, Uhm JH, Antel JP and Yong VW: Enhanced protein kinase $\mathrm{C}$ activity correlates with the growth rate of malignant gliomas in vitro. Neurosurgery 29: 880-886, discussion 886-887, 1991.

20. Couldwell WT, Antel JP and Yong VW: Protein kinase C activity correlates with the growth rate of malignant gliomas: Part II. Effects of glioma mitogens and modulators of protein kinase C. Neurosurgery 31: 717-724, discussion 724, 1992.

21. Baltuch GH and Yong VW: Signal transduction for proliferation of glioma cells in vitro occurs predominantly through a protein kinase C-mediated pathway. Brain Res 710: 143-149, 1996.

22. Inoue M, Kishimoto A, Takai Y and Nishizuka Y: Studies on a cyclic nucleotide-independent protein kinase and its proenzyme in mammalian tissues. II. Proenzyme and its activation by calcium-dependent protease from rat brain. J Biol Chem 252: 7610-7616, 1977. 
23. Kishimoto A, Takai Y, Mori T, Kikkawa U and Nishizuka Y: Activation of calcium and phospholipid-dependent protein kinase by diacylglycerol, its possible relation to phosphatidylinositol turnover. J Biol Chem 255: 2273-2276, 1980.

24. Castagna M, Takai Y, Kaibuchi K, Sano K, Kikkawa U and Nishizuka Y: Direct activation of calcium-activated, phospholipid-dependent protein kinase by tumor-promoting phorbol esters. J Biol Chem 257: 7847-7851, 1982.

25. Regala RP, Weems C, Jamieson L, Copland JA, Thompson EA and Fields AP: Atypical protein kinase $\mathrm{C}$ plays a critical role in human lung cancer cell growth and tumorigenicity. J Biol Chem 280: 31109-31115, 2005.

26. Takagawa R, Akimoto K, Ichikawa Y, et al: High expression of atypical protein kinase $C \lambda / \iota$ in gastric cancer as a prognostic factor for recurrence. Ann Surg Oncol 17: 81-88, 2010.

27. Desai SR, Pillai PP, Patel RS, McCray AN, Win-Piazza HY and Acevedo-Duncan ME: Regulation of $\mathrm{Cdk} 7$ activity through a phosphatidylinositol (3)-kinase/PKC-t-mediated signaling cascade in glioblastoma. Carcinogenesis 33: 10-19, 2012.

28. Patel R, Win H, Desai S, Patel K, Matthews JA and Acevedo-Duncan M: Involvement of $\mathrm{PKC}-\mathrm{\iota}$ in glioma proliferation. Cell Prolif 41: 122-135, 2008.

29. Donson AM, Weil MD and Foreman NK: Tamoxifen radiosensitization in human glioblastoma cell lines. J Neurosurg 90: 533-536, 1999.

30. Desai S, Pillai P, Win-Piazza H and Acevedo-Duncan M: PKCpromotes glioblastoma cell survival by phosphorylating and inhibiting BAD through a phosphatidylinositol 3-kinase pathway. Biochim Biophys Acta 1813: 1190-1197, 2011.
31. Jackson SP and Bartek J: The DNA-damage response in human biology and disease. Nature 461: 1071-1078, 2009.

32. He J, Li J, Ye C, et al: Cell cycle suspension: a novel process lurking in G2 arrest. Cell Cycle 10: 1468-1476, 2011.

33. Gaikwad NW and Bodell WJ: Peroxidase-mediated dealkylation of tamoxifen, detected by electrospray ionization-mass spectrometry and activation to form DNA adducts. Free Radic Biol Med 52: 340-347, 2012

34. Baldwin RM, Garratt-Lalonde M, Parolin DA, Krzyzanowski PM, Andrade MA and Lorimer IA: Protection of glioblastoma cells from cisplatin cytotoxicity via protein kinase $\mathrm{C}_{\mathrm{l}}$-mediated attenuation of p38 MAP kinase signaling. Oncogene 25: 2909-2919, 2006.

35. Baldwin RM, Parolin DA and Lorimer IA: Regulation of glioblastoma cell invasion by $\mathrm{PKCl}$ and $\mathrm{RhoB}$. Oncogene 27: 3587-3595, 2008

36. Schachter MM and Fisher RP: The CDK-activating kinase Cdk7: taking yes for an answer. Cell Cycle 12: 3239-3240, 2013.

37. Bicaku E, Patel R and Acevedo-Duncan M: Cyclin-dependent kinase activating kinase/Cdk7 co-localizes with PKC-ı in human glioma cells. Tissue Cell 37: 53-58, 2005.

38. Larochelle S, Merrick KA, Terret ME, et al: Requirements for $\mathrm{Cdk} 7$ in the assembly of Cdk1/cyclin B and activation of $\mathrm{Cdk} 2$ revealed by chemical genetics in human cells. Mol Cell 25: 839-850, 2007.

39. Yu J, Guo QL, You QD, et al: Gambogic acid-induced G2/M phase cell-cycle arrest via disturbing CDK7-mediated phosphorylation of CDC2/p34 in human gastric carcinoma BGC-823 cells. Carcinogenesis 28: 632-638, 2007. 